\title{
EFFECT OF RED LIGHT-BLUE AND NITROGEN STARVATION ON GROWTH OF MICROALGAE Tetraselmissp.
}

\author{
Thoriq Teja Samudra, Hilda Wati Nasution, Wiga Pratama, Chandra Pradhitaningrum, \\ Rezika Alyza, and Eko Agus Suyono \\ Biotechnology Laboratory, Faculty of Biology, \\ Gadjah Mada University, Yogyakarta \\ Corresponding author: Eko Agus Suyono \\ Email: eko_suyono@ugm.ac.id
}

\begin{abstract}
Microalgae has many benefits for human being. Microalgae is potential source for biodiesel and bioethanol, but the biomass produced from the culture is relatively low. So that, the research has to be done to improve the productivity of the microalgae. Red light and blue light spectrum are known as effective spectrums for the photosynthesis process. Then nitrogen starvation medium is usually performed in order to improve the lipid content. However, nitrogen starvation treatment will decrease microalgae biomass. Therefore, this research aims to study the effect of red and blue light and nitrogen starvation on the growth of Tetraselmis sp. The parameters measured were the cells number, dry weight and chlorophyll a and b. In this study, microalgae Tetraselmis sp. was treated using red and blue light for 7 days. Then, followed by nitrogen starvation treatment with concentration $100 \%, 50 \%$, and $0 \%$ of the $\mathrm{f} / 2$ normal medium until day 14 . The number of the cells was counted every day for 14 days using a haemocytometer and dry weights were counted at day $0,1,5,7$ and 14. Chlorophyll contents were calculated by Jeffrey and Humphrey's Trichromatic Equations method at absorbance $664 \mathrm{~nm}, 647 \mathrm{~nm}, 630 \mathrm{~nm}$, and $750 \mathrm{~nm}$. The results indicated that the red light increased the number of cells to twice as normal, while the blue light increased the number of cells to 1,5 times as normal. Furthermore, the $50 \%$ of nitrogen treatment under the red and blue light increased the dry weight to $25 \%$ and $60 \%$.

Key words: Microalgae, Tetraselmis sp., Nitrogen Starvation, Blue and Red light
\end{abstract}

\section{INTRODUCTION}

Nowadays, energy for human needs is increase. According Nuryadhyn (2012), in Indonesia, the energy consumption by the public is still focused on fossil fuel. Fossil fuel consumption is currently reaches 1.3 million barrels per day. Meanwhile, oil production by the contractor only reached 900,000 barrels per day. Therefore, it is necessary to develop alternative energy sources.

Alternative energy sources have actually been developed, they can be either bioethanol or biodiesel. Bioethanol and biodiesel using feedstock are derived from food crops such as oil palm, castor, sugarcane, corn, and soybeans.

One of the potential bio-based fuel sources is microalgae. Microalgae can produce lipids that can be used as a substrate for biodiesel. Compared with corn and palm oil, productivity of microalgae is much higher, where the productivity of biodiesel from microalgae can reach $58700 \mathrm{~L}$ / ha, while palm oil only 5,950 L / ha (Chisti, 2007). One of microalgae that potential to develop as a biofuel is Tetraselmis sp. which has a relatively high lipid content, which may reach $15-23 \%$ of the dry weight (Chisti, 2007).

The productivity of microalgae needs to be increased. It is done by optimizing its photosynthetic. Blue light and red light are known to be effectively used for photosynthesis reac- 
tion, because the best light absorption of chlorophyll is under blue light and red light. (Taiz \& Zeiger, 2002). In general, the blue light on microalgae increased photosynthetic activity. Furthermore, blue light also regulates metabolism in microalgae. In one study, blue light increased lipid productivity followed by increased productivity and decreased carbohydrate protein in microalgae (Marchetti et al., 2012). To increase the lipid content in microalgae culture stressing methods can be used to reduce the levels of $\mathrm{N}$ in the growth medium. This is because in these conditions the carbon metabolic pathway is directed to the synthesis of lipids (Allsul \& Omar, 2012; Hu, 2004).

\section{MATERIALS AND METHODS Materials}

Materials used in this study are Tetraselmis sp. ancol isolates, sea water, distilled water, alcohol, and chemicals to make the $\mathrm{f} / 2$ medium, The tools used in this study are thermometers, culture bottles, aerator, aerator hose, erlenmeyer, refractometer, $\mathrm{pH}$ indicators, autoclave, microscope, and haemacytometer.

\section{Tetraselmis sp. culture}

Tetraselmis sp. cultured in medium $\mathrm{f} / 2$ with a bottle. A total of $50 \mathrm{~mL}$ isolate Tetraselmis sp. Inoculat $\mu$...ñed in $150 \mathrm{~mL}$ of medium $\mathrm{f} / 2$, incubated for one week with continuous aeration and illumination. The cultures were incubated with a different light (blue, red, and white as a control). Lighting for 18 hours each day. After 1 week of microalgae cultures that had been treated with a different lighting transferred into a f/2 medium with a nitrogen content $100 \%, 50 \%$ and $0 \%$ of the prescription

\section{Growth Parameters}

The growth rate of Tetraselmis sp. was determined by measuring the number of cells, dry weight and the content of chlorophyll $a$ and $b$ in all treatments. Culture samples were taken every 24 hours during the incubation period. Number of cells was counted under a light microscope using a haemocytometer. Biomass productivity Tetraselmis sp. was measured by calculating the dry weight at the beginning and end of each treatment and control. Calculation of chlorophyll $a$ and $b$ was performed on days $0,1,3,5,7$, and 14 by using the Jeffrey and Humphrey's Tricrhomatic Equation method.

\section{RESULT AND DISCUSSION}

Table 1 showed that the growth of cultured microalgae Tetraselmis sp. with the highest number of cells was under the red light treatment with $50 \% \mathrm{~N}$ medium (4.8 million cells. $\left.\mathrm{ml}^{-1}\right)$. The highest dry weight was produced by culture of Tetraselmis sp.was under red light with $100 \%$ nitrogen $\mathrm{f} / 2$ medium. Highest chlorophyll content was obtained in cultures of microalgae Tetraselmis sp. treated with blue light.

The results showed that the red light was effective in increasing the number and dry weight of cells. This could be occurred because red light has a wavelength that could be used by Tetraselmis sp. to carry out the photosynthesis process effectively. So Tetraselmis sp. grown faster, it could be seen from the acquisition of cell number and dry weight of red 
light treatment. While blue light also had the optimal wavelengths for photosynthesis, but the blue light had more energy than red light (Marchetti et al., 2012). The blue light treatment effected on chlorophyll synthesize, because the blue light provided more energy for photosynthesis. The Tetraselmis sp adapted it by producing more chlorophyll.

Table 1. Number of cells, the amount of chlorophyll, and dry weight of Tetraselmis sp. on all treatments

\begin{tabular}{|c|c|c|c|}
\hline Treatments & Red light & Control & Blue light \\
\hline & $\Sigma$ Cell : 2,5 million cell. $\mathrm{ml}^{-1}$ & $\Sigma$ Cell : 2,3 million cell. $\mathrm{ml}^{-1}$ & $\Sigma$ Sel : 2,3 million cell. $\mathrm{ml}^{-1}$ \\
\hline Medium N & $\Sigma$ Chlorophyll : 6 ng.ml ${ }^{-1}$ & $\Sigma$ Chlorophyll : $7 \mathrm{ng} \cdot \mathrm{ml}^{-1}$ & $\Sigma$ Chlorophyll: $7,5 \mathrm{ng} \mathrm{ml}^{-1}$ \\
\hline \multirow[t]{2}{*}{$0 \%$} & Dry weight : $300 \mu \mathrm{g} \cdot \mathrm{ml}^{-1}$ & Dry weight : $310 \mu \mathrm{g} \cdot \mathrm{ml}^{-1}$ & Dry weight : $250 \mu \mathrm{g} \cdot \mathrm{ml}^{-1}$ \\
\hline & $\Sigma$ Cell: 4,8 million cell.ml ${ }^{-1}$ & $\Sigma$ Cell: 1,5 million cell.ml ${ }^{-1}$ & $\Sigma$ Cell : 3,2 million cell. $\mathrm{ml}^{-1}$ \\
\hline Medium N & $\Sigma$ Chlorophyll: $6 \mathrm{ng} \mathrm{ml}^{-1}$ & $\Sigma$ Chlorophyll : $7 \mathrm{ng} \cdot \mathrm{ml}^{-1}$ & $\Sigma$ Chlorophyll : $7,5 \mathrm{ng} \cdot \mathrm{ml}^{-1}$ \\
\hline \multirow[t]{2}{*}{$50 \%$} & Dry weight : $400 \mu \mathrm{g} \cdot \mathrm{ml}^{-1}$ & Dry weight: $325 \mu \mathrm{g} \cdot \mathrm{ml}^{-1}$ & Dry weight: $310 \mu \mathrm{g} \cdot \mathrm{ml}^{-1}$ \\
\hline & $\Sigma$ Cell : 3 million cell.ml ${ }^{-1}$ & $\Sigma$ Cell: 1,5 million cell.ml ${ }^{-1}$ & $\Sigma$ Cell : 2,1 million cell.m ${ }^{-1}$ \\
\hline Medium N & $\Sigma$ Chlorophyll: $6 \mathrm{ng} \mathrm{ml}^{-1}$ & $\Sigma$ Chlorophyll $: 7 \mathrm{ng} \mathrm{ml}^{-1}$ & $\Sigma$ Chlorophyll : $7,5 \mathrm{ng} \mathrm{ml}^{-1}$ \\
\hline $100 \%$ & Dry weight : $500 \mu \mathrm{g} \cdot \mathrm{ml}^{-1}$ & Dry weight : $320 \mu \mathrm{g} \cdot \mathrm{ml}^{-1}$ & Dry weight : $350 \mu \mathrm{g} \cdot \mathrm{ml}^{-1}$ \\
\hline
\end{tabular}

\section{ACKNOWLEDGMENT}

The authors would like to thank Dr. Ari Indrianto for allowing us to use Biotechnology Laboratory. This research was funded by the Directorate General of Higher Education of Indonesia.

\section{REFERENCES}

Alsull, M., and W.M.W. Omar. 2012. Responses of Tetraselmis sp. and Nannochloropsis $\mathrm{sp}$. isolated from Penang National Park coastal waters, Malaysia, to the combined influences of salinity, light and nitrogen limitation. International Conference on Chemical, Ecology and Environmental Sciences (ICEES 2012).

Chisti, Y. 2007. Biodiesel from microalgae. Biotechnology Advances 25 294-306.

Hu, Q. 2004. Environmental Effects on Cell Composition. Dalam: Richmond, Amos ed. Handbook of Microalgal Culture: Biotechnology and Applied Phycology. Blackwell Science: India. P. 86

Marchetti, J., G. Bougaran, T. Jauffrais, S. Lefebvre, C. Rouxel, B. Saint-Jean, E. Lukomska, R. Robert, and J.P. Cadoret. 2012. Effects of blue light on the biochemical composition and photosynthetic activity of Isochrysis sp. (T-iso). Journal of Applied Phycology. 2012. P 6.

Nuryadhyn, A. 2012. Herman: Konsumsi BBM 1,3 Juta Barel Per Hari. http://bangka. tribunnews.com, Accessed 10 September 2012.

Taiz, L., and E. Zeiger. 2002. Plant Physiology 3th ed. Sinauer Associates. Sunderland. England. 